\title{
Kategeet en geloofsvorming: Perspektiewe vanuit die Praktiese Teologie
}

Author:
Casper J.H. Venter
Affiliation:
1Faculty of Theology,
North-West University,
Potchefstroom Campus,
South Africa
Correspondence to:
Cassie Venter
Email:
casmar@lantic.net
Postal address:
3 Agapanthus Street,
Welgedacht 7530,
South Africa
Dates:
Received: 25 Mar 2011
Accepted: 17 June 2011
Published: 04 Nov. 2011
How to cite this article:
Venter, C.J.H., 2011,
'Kategeet en geloofsvorming:
Perspektiewe vanuit die
Praktiese Teologie', HTS
Teologiese Studies/
Theological Studies 67(3),
Art. \#1052, 8 pages. http://
dx.1052

(C) 2011. The Authors. Licensee: AOSIS OpenJournals. This work is licensed under the Creative Commons Attribution License.

\section{Catechist and the forming of faith: Practical-theological perspectives}

Scrutinising this topic is an attempt to equip catechists more extensively in serving and furthering the forming of faith in the process of formal catechesis given to children. An additional aim is to highlight an outcome indicated in certain practical-theological studies, that is, that the rational dimension in the forming of faith should not be accentuated one-sidedly in formal catechetical ministry within faith communities. On basis-theoretical level the following aspects are investigated: a closer definition of faith from Hebrews focusing on the forming of faith by means of catechesis; the action of learning in the forming of faith; the sequence in the action of teaching as indicated in Scripture; the gifts of the Holy Spirit in intermediating the process of forming faith; the way and attitude in which the catechist fulfils his or her ministry, and in last instance, the spirituality of the catechist. On metatheoretical level applicable aspects from the field of Emotional and Social Intelligence are investigated. Data from the field of Emotional Intelligence that should be part of the catechist's teaching equipment point to the necessity of being conscious of aspects such as self-awareness, self-control, self-motivation and social skills. Contributions from the field of Social Intelligence include attitudes and skills like empathy, the ability of presenting oneself effectively in formulating ideas, the authority with which the catechist communicates, and his or her caring for someone else's needs. In final instance, relevant practice-theoretical perspectives that can be applied in catechetical ministry, and specifically in the forming and passing on of faith, are outlined.

\section{Oriëntering}

In die afgelope ongeveer tien jaar is in navorsing oor Praktiese Teologie opnuut en by herhaling gefokus op die vereistes wat gestel word vir en die inhoud van die bediening van die predikant, en dus ook vir die opleiding tot hierdie bediening. Buys (2010:48) stel die kernvraag: '... hoe moet teologiese opleiding van kerklike voorgangers herstruktureer word ten einde kerke effektief geestelik en in getalle te laat groei?.' Afgesien van geestelike en getallegroei word die grootste nood ook aangedui, naamlik dat dosent, predikant en sendeling God self in al sy majesteit, soewereiniteit en heerlikheid beter sal leer ken; 'n vereiste wat inhou om in 'n persoonlike en lewende verhouding met God te lewe. Nel (2005:448) raak'n ander aspek in hierdie tipe navorsing aan, omdat hy sy ondersoek veral rig op die vaardighede en karaktereienskappe wat nodig is vir 'n bedienaar in hierdie tyd, naamlik kennis, insig, die regte gesindheid en ingesteldheid (vgl. ook Breed 1994:136). Nel (2005:455) beklemtoon die aspek van vaardighede en die rol van emosies, en bedoel daarmee dat die bedienaar ook van toepaslike gegewens uit die sosiale wetenskappe gebruik behoort te maak, gegewens wat van toepassing is op spesifieke aspekte van konkrete situasies waarmee die bedienaar op praktiese vlak te doen kry. Ook die wyse en styl van optrede moet beklemtoon word. Afgesien van navorsing oor die opleiding van die bedienaar in ons tyd, fokus navorsing in Praktiese Teologie en aanverwante navorsingsgebiede ook op die optrede van die bedienaar (vgl. Venter 2004:429-449), sy persoon en persoonlikheid (Nel 2001:17-20), sy gesondheid en gesindheid (Kruger 2002:87-92), die belangrikheid en bepaalde wyses waarop die konteks in ag geneem behoort te word (Augier, Sharig \& Vendeloa 2001:125-136), en bepaalde toestande wat by kinders 'n saak soos geloofsvorming kan belemmer (Schoombee \& Van Zyl 2011:53-67).

Binne die breër navorsingsvelde, soos hierbo aangedui is, vind navorsing oor die vakgebied Kategetiek, spesifiek oor die kategeet en geloofsvorming, dan 'n eiesoortige plek in hierdie artikel, tesame met 'n navorsingsveld binne die Psigologie as wetenskap, naamlik Emosionele Intelligensie (EI) en Sosiale Intelligensie (SI). Die onderwerp wat ondersoek word, leen hom daartoe om sowel op basisteoretiese vlak (kategeet en geloofsvorming) as op metateoretiese vlak (die vlak van hoe geloofsvorming sinvol en emosioneel-verantwoord behoort plaas te vind) verken te word. In hierdie artikel word nie op die vraagstuk van die verhouding tussen die vakgebiede Teologie, Psigologie en Opvoedkunde ingegaan nie. In die teorievorming word basisteoretiese 
aspekte ontgin, gevolg deur metateoretiese aspekte. Albei word in ' $n$ hermeneutiese wisselwerking met die oog op praktykteoretiese riglyne ontgin.

Binne die wyer raamwerk van navorsing oor die kategese en kategeet wat die afgelope tien jaar die lig gesien het, is daar raakpunte met hierdie artikel. Hier word na die volgende toepaslike wetenskaplike publikasies verwys. Van der Merwe (2004) ondersoek in sy proefskrif die fundering en uitwerking van die verwerkliking van die Woord in die kerklike kategese. Hierbinne ontvang die ondersoek na die verseëling deur die Heilige Gees as eiendom van God 'n besondere aksent, asook die dogmatiese omskrywing van geloof as fides quae creditur [die dinge wat ons glo] en as fides qua creditur [die geloof waardeur geglo word] in geloofsvorming deur die bediening van die Woord in die kerklike kategese. In die proefskrif van Hoffman (2010), kom sy na basisteoretiese navorsing en gefundeerde empiriese navorsing tot die ontwerp van 'n verantwoorde raamwerk vir 'n kategesemodel as bruikbare middel in onderrig tot geloofsvorming. De Wet (2003) neem as navorsingstema die volgende: "n Gemeenskapsgerigte model vir geloofsvorming van tieners in die verbondsgesin deur middel van simbole en rituele'. Die fokus is hierin nie direk gerig op geloofsvorming in die kerklike kategese nie, maar bied waardevolle perspektiewe vir geloofsvorming binne die kring van die gesin.

Wat die buitelandse navorsingstoneel oor die onderhawige tema betref, word in hierdie artikel slegs verwys na die ondersoek van Strommen en Hardel (2000), waarin veral vanuit die persoonlike verhouding met God as vertrekpunt nader ingegaan word op geloofsoordrag. In 'n vroeëre werk behandel Groome (1991) geloofsoordrag vanuit verskillende dogmatiese en historiese oogpunte. Warren (2001:125-144) bied ' $n$ historiese oorsig oor die aksie en instelling van kategese sedert die antieke tyd.

Vanuit bogenoemde navorsingsvelde in die Kategetiek kom ook ' $n$ ander aspek na vore wat met geloofsvorming verband hou. Uit empiriese en tersaaklike vakliteratuur blyk dat in die praktyk van die kategese as middel tot geloofsvorming in 'n groot mate net op rasionele kennisvlak met die Bybel en ander leerstof, byvoorbeeld die belydenisskrifte, omgegaan word met die oog op geloofsverwerkliking (Venter \& Van der Merwe 2005:113). Inderdaad is geloof wel ook 'n gewisse kennis wat voortvloei uit prediking en onderrig uit die Woord van God deur die inwerking van die Heilige Gees. Die geloofsvertroue op God se beloftes moet egter oorgaan in gelééfde geloof op grond van die belewing van die heil in Jesus Christus. Geloof het ook 'n ervaringselement. Joubert (2009:73-74) toon aan dat dit juis hierdie aspek is, gelééfde of ervaarde geloof, dit wil sê die geïntegreerde verband en verhouding tussen geloof as kennis en geloof as ervaring, wat tans ' $n$ besondere navorsingsveld in die Praktiese Teologie geword het.

Die oordrag van die Woord in kategese, met die oog op geloofsvorming, vind plaas deur die kategeet wat hierin in diens van God en sy Woord staan. Juis deur die onderrig van die kategeet met die oog op die aksie van geloofsvorming kom bepaalde vrae na vore wat op basisteoretiese en op metateoretiese vlak nader ondersoek behoort te word. Sodanige vrae sluit byvoorbeeld die volgende in: Waarin is 'n nadere definiëring van geloof in geloofsvorming geleë? Waaruit bestaan die aksie van leer in geloofsvorming wat deur die kategeet aangewend word? Is daar 'n bepaalde volgorde in die proses van leer? Met watter gesindheid behoort die kategeet besig te wees met geloofsvorming? Hoe vind geloofsidentifisering tussen kategeet en katkisant plaas? Hoe beleef die kategeet sy eie spiritualiteit in die onderrig tot geloofsvorming by die katkisant?

\section{Basisteoretiese perspektiewe Geloof en die proses van geloofsvorming}

Ter wille van die logiese gang en opbou in hierdie besinning is dit nodig om vooraf nader te omskryf wat met geloof bedoel word. In kern word geloof in kerklike belydenisskrifte as 'n gewisse kennis en 'n vaste vertroue omskryf (Sondag 7 van die Heidelbergse Kategismus; vgl. Gereformeerde Kerke in Suid-Afrika 2001:38-39).

Op dogmatiese vlak word in omskrywings van geloof veelal tussen fides quae creditur en fides qua creditur onderskei. Met eersgenoemde word bedoel die objektiewe geloofsinhoud. Geloof volgens hierdie benoeming is dus die inhoud van wat geglo word, en dit word deur God se openbaring bepaal. Laasgenoemde benoeming, fides qua creditur, beteken letterlik die geloof waardeur geglo word, die geloof waardeur heil en versoening aanvaar word, en waardeur gekom word tot geloofsvorming en verbondsinwilliging (Venter \& Van der Merwe 2005:116).

Vanuit bogenoemde breër raamwerk en onderskeiding van wat onder geloof verstaan behoort te word, word nou 'n basisteoretiese ekskursie onderneem om vanuit die enigste direkte definisie in die Nuwe Testament van wat geloof is, ' $n$ nadere verkenning te doen van bepaalde perspektiewe met die oog op geloofsvorming.

In Hebreërs 11:1 word geloof in twee kernbegrippe omskryf: 'Om te glo is om seker te wees van die dinge wat ons hoop, om oortuig te wees van die dinge wat ons nie sien nie.'

Die uitdrukking 'om seker te wees' word in Hebreërs 11:1 weergegee deur 'n selfstandige naamwoord, hupostasis, wat 'n wye gebruiksveld in die Nuwe Testament het. Hupostasis dui byvoorbeeld op die wesenlike aspek van 'n saak, die versekering, waarborg of ook wetlike dokumente wat bewys lewer van eienaarskap (vgl. Rienecker 1980:360). Die gebruik van hupostasis in die papiri beklemtoon die onderliggende gedagte van geloof as die 'waarborg' van toekomstige besit, byvoorbeeld van 'n eiendom. Die term 'titelakte' gee op verantwoorde wyse die betekenis van hupostasis weer (vgl. Hewitt 1975:171). Die belangrike gevolgtrekking vir geloofsvorming is dat geloof hier omskryf word as vaste bewyse waaraan nie getwyfel hoef te word nie. Die tweede 
verbandhoudende uitdrukking wat in Hebreërs 11:1 in die definisie van geloof gebruik word, is dié van elengmos wat ook die konnotasie van 'n 'wetlike bewys' het, byvoorbeeld van 'n aanklag teen 'n beskuldigde.

Die vasstelling dat geloof aspekte soos gewaarborgde sekerheid vir die toekoms waarop gehoop word omvat, en dat geloof self ook die bewys omvat van die dinge wat ons (nog) nie sien nie, word as 'n bepaalde vertrekpunt in hierdie artikel oor geloofsvorming in die kategese aanvaar.

Hoewel verder in die artikel nader ingegaan word op geloofsidentifikasie, moet in die behandeling van toepaslike gegewens uit Hebreërs reeds daarop gewys word dat die nadere definisie van geloof in Hebreërs 11:1 direk gevolg word deur praktiese en toegepaste voorbeelde van hoe geloof in die lewe van die geloofshelde in die verlede gefunksioneer het. ' $n$ Enkele voorbeeld van hoe geloof oorgaan in aksie word ter illustrasie aangehaal: 'Omdat Noag geglo het - het hy die ark gebou om sy huisgesin te red' (Heb 11:7).

Op 'n verdere toepaslike aspek van geloof uit Hebreërs 12:1 word hier gewys vanuit die breër struktuur van Hebreërs. Aan die einde van Hebreërs 5 is dit duidelik dat die rede vir vermaning in die breër opset van Hebreërs juis uit 'n leeragterstand ontstaan het. Die gemeente moes self al lankal ander mense kon onderrig vanuit die Woord, maar moes self weer in die grondwaarhede van die geloof onderrig word. Hulle het traag geword om te leer. Vanuit die traagheid om te leer, oor die definisie van geloof heen in Hebreërs 11, en van die opnoem van geloofshelde met wie geïdentifiseer kan word, word dan, ná die uiteensetting van geloof as titelakte, gekom by die aanmoediging om te volhard: 'Laat ons daarom die wedloop wat vir ons voorlê, met volharding loop' (Heb 12:1).

Geloofsvorming moet uitloop op die belewing van geloof en die volharding in geloof.

\section{Die aksie van leer}

Nel en Thesnaar (2006:101-102) stel dat 'n kernelement in jeugbediening die herontdekking van die leerdiens van die kerk is. Hulle begrond die standpunt nader deur daarop te wys dat die daad van leer in die Ou Testament begeleiding op die weg ingehou het. Dit hou begeleiding in die aksie van hoe iemand behoort te lewe in (Spr 22:6), en ook dat daar ' $n$ sekere lewensbestemming is waarheen die begeleiding lei. Die vroegste onderrig van 'n Joodse kind was gerig op onderrig in die weg van God met sy volk. Hierdie onderrig het op so 'n wyse geskied dat die kind al meer en meer ervaar en beleef het dat God se weg met sy volk ook God se weg met hom (die kind) is, naamlik 'teaching as initiation is first of all an act of implicating the young Israelite in the story of salvation' (Nel \& Thesnaar 2006:102).

Die uitdrukking 'op die weg' impliseer ook die aspek van begeleiding tot wysheid as praktiese lewenswysheid. Juis hierdie begeleiding het langs die weg van onderrig in die
Tora plaasgevind. So het die kind gekom tot onderskeiding van wat die beste in hierdie bepaalde werklikheid is.

Op die vlak van die Nuwe Testament word daar in hierdie artikel veral aandag gewy aan die gebruik van die begrip didaskein [om te leer]. Louw en Nida (1989:413) plaas genoemde begrip binne die semantiese subdomein van onderrig, en dan wel onderrig wat verband hou met 'n proses om iemand te bring tot die aksie van leer of om te weet, maar dan in 'n voortgaande aksie van formele en informele leer. Louw en Nida (1989:414) beklemtoon dat dit belangrik is om in die soeke na 'n geskikte uitdrukking vir leer, nie 'n uitdrukking te kies wat alleenlik op formele klaskameraktiwiteite dui nie. Hiermee word beklemtoon dat onderrig formeel en informeel behoort te wees. ' $n$ Verdere aspek ingebed in die begrip leer is dat didaskein op 'n voortgaande proses van persoonlike betrokkenheid deur ' $n$ leermeester in die begeleiding van ' $n$ leerling in die leeraktiwiteite dui. Hierdie onderrig behels ' $n$ stap-vir-stap en nadere ontvouing van die heilsgebeure en die aanvaarding daarvan om sodoende tot geloofsvorming onder die leiding van die Heilige Gees te kom (Dingemans 1986:135-138).

\section{Die volgorde in die leeraksie}

Dit is opvallend dat die opdrag om ander te leer deel is van die laaste, omvattende bevele van die Here Jesus aan sy dissipels. In Matteus 28:18-20 word die bevel om te leer deur Christus in ' $n$ bepaalde konteks gestel. Allereers is daar ' $n$ sentrale indikatief: 'Aan My is gegee alle mag in hemel en op aarde.' Daarna volg die bevel: 'Gaan dan na al die nasies ... en leer hulle.' Die indikatief dat aan Jesus alle mag gegee is, word gevolg deur die bevel om te leer, en die bevel om te leer word gevolg deur die belofte: 'En onthou: Ek is by julle al die dae tot aan die voleinding van die wêreld.' Hierdie volgorde in die leeraksie is belangrik vir kategese tot geloofsvorming: die imperatief tot onderrig en die onderrigaksie self berus altyd in die indikatief, en nie omgekeerd nie. Die imperatief ('Gaan dan ...') word nie onderrig om by die indikatief uit te kom nie, maar juis vanuit die sentraliteit van die indikatief. Verder word die imperatief dikwels direk of by implikasie deur die beloftes van God se verbond gevolg.

'n Kernmoment in die kategeet se geloofsvorming van die verbondskind is geleë in die verkondigingsvolgorde soos hierbo uiteengesit.

\section{Leer en gawes om te leer}

Vervolgens word ook gewys op die werk van die Heilige Gees in die leeraksie vanuit die Woord. Die werk van die Heilige Gees kom na vore daarin dat 'die bedienaar wat leer', aangedui word as ' $n$ bepaalde charisma van die Heilige Gees. In Romeine 12:6-8 beskryf Paulus die gawes wat die Heilige Gees tot opbou van die gemeente gee. Hy beklemtoon in besonder die verskeidenheid gawes wat die Gees gee. In volgorde word die gawes hier soos volg weergegee uit Romeine 12:6-8: God se boodskap moet verkondig, dien, 'onderrig gee', bemoedig, leiding gee, help. Dit is opvallend dat juis 'n sewetal gawes hier uitgelig word om te beklemtoon 
dat God 'n volheid van gawes tot opbou van die gemeente gee. Hiervan is 'onderrig gee' een.

\section{Die wyse en gesindheid waarin geleer word}

Wat die aksie van leer betref, moet ook kortliks stilgestaan word by bepaalde perspektiewe vanuit die Pastorale Briewe wat betrekking het op die wyse van optrede van die een wat die Woord ter geloofsvorming oordra. In 1 Timoteus 2:24 word die volgende gesê: "n Dienaar van die Here moenie rusie maak nie. Inteendeel hy moet vriendelik wees teenoor almal, bekwaam om ander te leer ...' In vers 25 word die begrip 'vriendelik' herhaal as gestel word: 'Met vriendelikheid moet hy teenstanders teregwys ...' Die Griekse uitdrukking wat hier vir 'vriendelik' gebruik word, is epios en wel in die betekenis van 'sag en liefdevol' (vgl. Bauer 1979:348). In 1 Tessalonisense 2:7 stel Paulus in 'n beeld dat hulle as apostels liefdevol en sag teenoor die gemeente opgetree het soos "n ma teenoor haar kinders'. Die 'sagte' optrede van 'n moeder word in hierdie gedeelte weergegee met nepios. Daar is ' $n$ fyn betekenisnuanse tussen die twee uitdrukkings epios en nepios, soos tussen 'sag' versorg en versorg soos 'n 'baba'.

Die tipe optrede waarmee onderrig tot geloofsvorming deur die kategeet moet plaasvind, moet wees soos die optrede van 'n ma teenoor kinders.

Met bogenoemde optrede hang ook ten nouste saam 'n vereiste wat in die Pastorale Briewe gestel word, naamlik dat 'n bedienaar nie net bekwaam moet wees om ander te leer nie (1 Tim 3:2), maar ook dat hy 'sy eie gesin goed kan beheer en in alle opsigte op waardige wyse gesag oor sy kinders kan uitoefen' (1 Tim 3:4).

Die twee beelde (dié van die moeder se versorging van haar kinders en dié van die vader wat op 'n waardige manier gesag uitoefen oor sy gesin) beklemtoon die aspek van verhoudingvorming met die oog op geloofsvorming in die kategese. Kategese is geen afstandsonderrig met die oog op die kliniese oordra van kennis nie, maar dit is wel onderrig binne ' $n$ verhouding. (In die metateoretiese afdeling word op ander aspekte van verhoudingvorming in die onderrig ingegaan.)

'n Ander dimensie van onderrig langs die weg van verhouding kom in Hebreërs 5:11-14 na vore. Hier stel die Hebreërprediker dat die gemeente traag geword het om te hoor, dat hulle al lankal gelowiges is en reeds self leermeesters moes wees, maar self nog in die geloofslewe van melk moet lewe. Dit is ' $n$ skerp vermaning op 'n vlak waar die leeraksie van gemeentelede skraal geword het. Die Hebreërprediker wil nie weer opnuut die fondamente lê deur die eerste basiese onderrig te herhaal nie, maar wil voortgaan om oor die dieper waarhede onderrig te gee. Tog, ten spyte van die skerp vermaning oor die gemeente se traagheid om te luister, in te neem en te wil leer, spreek die prediker hulle nog steeds as 'geliefdes' aan (Heb 6:9). Hy bly lief vir hulle. Hy wil sy 'geliefdes' verder onderrig. Hy wil hulle onderrig tot geloofsvorming wat tot geloofsgroei sal lei. Hier het ons dus te doen met vermaning in 'n onderrigsituasie, maar dan aan 'geliefdes' - die enigste keer dat die aanspreekvorm 'geliefdes' in Hebreërs voorkom.

Dit is wel verder ook so dat Paulus vir Timoteus aanspreek as 'my eie kind in die geloof' (1 Tim 1:1), as 'my geliefde seun', en vir Titus as 'my eie kind in die geloof' (Titus 1:4). Afgesien van die verhouding waarin Paulus, as hulle leermeester, tot hulle staan (vgl. Stott 1997:26), sit hier nog iets meer in die aanspreekvorm 'geliefdes'. Ook in 1 Korintiërs 4:14 noem Paulus dit dat hy die Korintiërs teregwys 'as my geliefde kinders'. En dan stel Paulus die rede waarom hy hulle 'geliefde kinders' noem, naamlik 'deur die verkondiging van die evangelie is ek in Christus Jesus julle vader ...' (1 Kor 4:15). In Paulus se onderrig aan Timoteus en Titus staan hulle nie alleen in die verhouding van 'geliefde kinders' tot hom nie. Hy staan in sy onderrig ook tot hulle in die verhouding van 'n vader wat hulle onderrig.

\section{Geloofsvorming deur identifikasie}

Die uitdrukking 'identifikasie' kom nie in die Nuwe Testament voor nie, maar die saak van identifikasie wel, onder meer in uitdrukkings soos 'voorbeeld' en 'navolger'.

In 2 Timoteus 1:5 is Paulus daaroor uitgesproke dat Timoteus 'n opregte geloof het. Hier trek Paulus die lyn van geloofsvorming van die grootouers en ouers deur na Timoteus. Timoteus se ouers en grootouers het nie die ongeveinsde geloof in Timoteus bewerk nie. Dit kan net die Heilige Gees deur die verkondiging van die woord doen. Die ouers en grootouers het die ongeveinsde geloof instrumenteel oorgelewer. Stott (1997) verwoord die geloofsvorming hier soos volg:

True, no man can inherit his parents' faith in the way that he inherits facets of their personality. But a child can be led to faith by his parents' teaching, example and prayers.

(Stott 1997:27)

Dit is opvallend hoe oortuig Paulus is dat die geloof in Timoteus as resultaat van voorafgaande geloofsvorming deur sy grootmoeder en moeder gevestig is. Paulus spreek sy vaste oortuiging hieroor uit in die gebruik van die uitdrukking pepeismai [ek is oortuig] in die perfektum-werkwoordsvorm. So praat Paulus oor die geloof wat reeds in die verlede langs die weg van geloofsvorming plaasgevind het. Die resultate daarvan is en bly steeds sigbaar in die hede.

In 1 Korintiërs 11:1 beveel Paulus: 'Volg my voorbeeld, soos ek die voorbeeld van Christus volg.' Hierdie bevel staan in die konteks van Paulus se uiteensetting oor die offervleis en die vryheid van die gelowige. Die afloop van Paulus se beredenering loop uit op ' $n$ aantal kernuitsprake: 'Doen alles tot eer van God', 'Moenie aanstoot gee nie', 'Maak soos ek maak', gevolg deur die opdrag: 'Volg my voorbeeld, soos ek die voorbeeld van Christus volg.' Die uitdrukking wat hier as voorbeeld gebruik word, is mimesis, wat inhou dat die gemeente Paulus in hierdie opsig moet nadoen en navolg in sy optrede (Van Wyk \& Venter 2003:535-536). Die gedagte hier is dié van identifikasie of modellering. Die Korintiërs 
moet kyk na wat Paulus doen, waarom hy dit doen, hoe hy dit doen, hulle daarmee vereenselwig en dan dieselfde gaan doen. Hiervoor is Paulus 'n voorbeeld in sy optrede en moet die gemeente hom navolg. Die voorbeeld waarvolgens Paulus optree, is die voorbeeld van Christus wat sy eie vryheid prysgegee het. In sy optrede bly Paulus dus slegs 'n vingerwysing na Christus en sy optrede. Daarin bestaan die ware geloofsvryheid van die gemeente (vgl. ook Breed \& Venter 1996:57-72).

Die Heilige Gees gebruik geloofsonderrig en geloofsvorming as proses om deur geloofsidentifikasie geloofsoordrag te bewerkstellig.

\section{Geloofsvorming: Kategeet en spiritualiteit}

Spiritualiteit kan omskryf word as die persoonlike verhouding van liefdesintegriteit waarin die gelowige tot God staan, of kortweg as die vormgewing van die persoonlike geloofsverhouding van die kategeet in die daaglikse lewe (vgl. Dreyer 1998:122; Van der Merwe 2004:425).

In die Pastorale Briewe kom twee sinonieme Griekse begrippe vir spiritualiteit in vyf gedeeltes na vore. In 1 Timoteus 4:7-8 en 11 en 2 Timoteus 3:12 word die uitdrukking eusebeia of eusebos gebruik; in 2 Timoteus 4:12 word hagneia gebruik en in 2 Timoteus 1:9 die begrip hagios (Venter 1999:189-190). Die begrip eusebeia dui op toewyding, eerbied (Eng: 'piety') en godsvresendheid en vind sterk toepassing in die wyse waarop prakties as gelowige geleef word (vgl. Stott 1997:117). Die begrip 'heiligheid' het die konnotasie van suiwerheid en opregtheid in die persoonlike toewyding aan God, die Heilige.

Die vorming in voortgaande geloofsverdieping by die kategeet self vind plaas deur persoonlike omgang met God in Skrifstudie, bepeinsing en gebed in die binnekamer.

\section{Samevatting van basisteoretiese perspektiewe}

- Vanuit Hebreërs kan geloof as gewaarborgde sekerheid vir die toekoms omskryf word, en as 'n wetlike bewys van dit wat ons vandag nog nie sien nie.

- Die kategeet is instrument van die Heilige Gees tot, en ontvang gawes van die Gees vir begeleiding tot geloofsvorming.

- Die aksie van begeleiding deur die kategeet tot geloofsvorming van katkisante kan omskryf word as 'n voortgaande proses van formele en informele leer wat 'n stap-vir-stap- en nadere ontvouing van die heilsgebeure inhou en van die persoonlike betekenis daarvan vir die katkisant se eie geloofsvorming en volharding in die geloof.

- Die identifikasie met die kategeet en ouers as geloofsrolmodelle bevorder en verdiep die proses van geloofsvorming.

- Die leeraksie in die proses van geloofsvorming geskied langs die weg van die oordrag van die Woord in die volgorde van indikatief, imperatief en belofte.
- Die kategeet moet in staat wees om onderrig tot geloofsvorming aan te bied in ' $n$ vriendelike gesindheid en in 'n verhouding soos dié van 'n moeder wat haar kinders troetel en van 'n vader wat in 'n persoonlike verhouding met sy kinders staan.

- Voordat onderrig tot geloofsvorming kan plaasvind, moet die kategeet self eers in 'n persoonlike verhouding tot God staan. ' $n$ Kategeet is eers kind van God en dan kategeet in diens van God met die oog op geloofsvorming.

\section{Metateoretiese perspektiewe}

In hierdie onderafdeling word die toepaslikheid van bepaalde snitte uit metateoretiese materiaal ondersoek. Uiteraard kan in hierdie navorsing op verskillende onderafdelings van die Psigologie gefokus word, byvoorbeeld op aspekte in verband met die ontwerp van kategesemodelle (vgl. Hoffman 2010:97-128) of op dimensies in die Psigologie oor die verskillende leeftydsfases en insigte wat daaruit voortvloei vir die katkisant en kategeet in verband met geloofsvorming in die kategese (vgl. Hoffman 2010:105). Ook gegewens uit die Kommunikasiekunde sou betrek kon word in die bespreking van die leeraksie met die oog op geloofsvorming.

In hierdie onderafdeling word veral op gegewens uit die vakgebiede $\mathrm{EI}^{1}$ en SI gefokus wat op die wyer vakgebied van die Psigologie lê. In hierdie artikel word die fokus egter meer op 'n nadere verkenning van toepaslike data vanuit die vakgebiede EI en SI gerig wat die kategeet in sy onderrig en optrede kan aanwend. EI en SI is juis nuwer gebiede in die Psigologie wat nader verken behoort te word met die oog op diensbaarheid in geloofsvorming.

\section{Toepaslike perspektiewe uit die vakgebied Emosionele Intelligensie}

Verskillende outeurs, byvoorbeeld Salovey, Mayer en Caruso (2002:160 e.v.) stel dat vanuit die breë vakgebied, EI, tussen die vaardigheid en vermoë van verstandelike intelligensie, EI en SI onderskei moet word. Verstandelike intelligensie fokus in besonder op rasionele werk (leeraksies), soos ook by die die kategeet en katkisant, terwyl EI met 'n ingesteldheid werk wat by die kategeet moet wees, naamlik die vermoë om eerstens eie gevoelens te herken in selfmotivering, en om eie emosies te onderskei (vgl. Goleman 1997:4-10) in die onderrig van katkisante. SI beweeg op die terrein van die herkenning van en insig in die katkisant se emosies, sosiale situasie en konteks en vaardighede om bepaalde sosiale situasies te hanteer (Goleman 2006).

'n Verkenning van die moontlike bydrae uit die vakgebied Emosionele Intelligensie

Gegewens vanuit die vakgebied, EI, kan bydra tot die kategeet se eie bewusmaking om die vermoëns en vaardighede van EI self toe te pas en te beoefen. Dit is vanselfsprekend dat so 'n ingesteldheid ook vir die kategeet in sy toerusting en onderrig tot geloofsvorming baie kan beteken. In hierdie verband, verwys Venter (2005:14-15) na selfbewussyn, selfbeheer, selfmotivering en sosiale vaardighede. 
Selfbewussyn hou nie vir die kategeet in om selfbewus te wees nie, maar om selfinsig te besit, te weet wat hy self op 'n bepaalde tydstip voel, dit te kan verwoord en te implementeer in byvoorbeeld besluite wat op daardie oomblik geneem moet word. Dit behels ook 'n nugter beskouing van eie vermoëns en 'n gefundeerde selfvertroue. Ten opsigte van selfbeheer moet 'n kategeet die vermoë besit om sy eie emosies te hanteer en diensbaar te stel aan sy taak van geloofsvorming. Hy of sy moet die vermoë verder oefen om erkenning en vergoeding vir hom- of haarself uit te stel, om te herstel van emosionele verwonding en om vernuwend te dink en aanpasbaar te wees. Beheersing van frustrasie en aggressie en uiteindelike woede-uitbarstings, vorm ook deel van selfbeheer. Selfmotivering omvat die stel van prioriteite om doelwitte te bereik, inisiatief te neem, na uitnemendheid te streef, asook om te volhard en positief te bly te midde van frustrasie en teenspoed. Sosiale vaardighede rus die kategeet toe om die plek en rol van eie emosies in onderlinge verhoudinge te herken, te kan hanteer, emosionele situasies reg te kan opsom, sinvol met mense om te gaan, eie vaardighede te kan gebruik om te oortuig, leiding te neem en te onderhandel, en in groepsverband saam te werk. Leierskap, kommunikasievaardighede en konflikhantering is alles aspekte vanuit die kennisveld van EI wat die kategeet kan toerus om waarlik diensbaar in geloofsvorming by die katkisant te wees. Hier moet in die lig van bogenoemde stelling dat EI, as lewensvaardigheid, in die algemeen veral met die eie gevoelens en belewing te doen het, kortliks ingegaan word op ' $n$ nadere aanduiding van die hoofemosies waarmee ' $n$ kategeet te doen kan kry in homself en in ander (Venter 2005:14-15).

Vermeulen (1999:43) stel dat 'n emosie 'n innerlike toestand is wat voortvloei uit wat ons dink en motiveer, en wat aangenaam of onaangenaam kan wees. In bogenoemde omskrywing is dit belangrik om te weet dat emosies hulle oorsprong in denke vind. Gevoelens verander nie, maar dit wat'n mens dink, die oorsprong van gevoelens, kan verander.

Bedell en Lennox (1997:54) onderskei die vernaamste tipe emosies:

- Vrees tree in as iemand verwag dat iets gaan gebeur wat hy of sy nie wil hê moet gebeur nie.

- Woede vlam op wanneer iemand wat iets wil hê, dit nie kry nie, en dit steeds wil hê.

- Droefheid word ervaar as iemand graag iets wil hê, dit nie kry nie en hoop opgee om dit ooit te kry.

- Geluk tree in wanneer iemand iets graag wil hê en dit wel kry.

Uiteraard is daar emosies wat moeilik onder een van hierdie vier hoofde gekategoriseer kan word, byvoorbeeld skugterheid, stilte, onvoldaanheid, en gevoelens van versteurdheid.

Samevatting van metateoretiese perspektiewe vanuit die vakgebied, Emosionele Intelligensie

Basiese kennis van toepaslike elemente uit die kennisveld van EI kan die dienswerk tot geloofsvorming vir die kategeet op verskeie vlakke verdiep:
- Insig in die eie gevoelens en emosies van die kategeet en hoe om emosioneel intelligent met eie gevoelens om te gaan te, dit te verwoord en te hanteer, kan verskerp word deur basiese kennis vanuit die vakgebied EI.

- Die vermoë om eie gevoelens diensbaar te stel aan die daad van geloofsvorming in die kategese, vernuwend te dink, aanpasbaar te wees en eie frustrasie te kan beheer word geoefen.

- Basiese kennis van EI kan bepaalde vaardighede verskerp, byvoorbeeld die beheer van frustrasie en aggressie in 'n klassituasie, en ook die vermoë om emosies reg op te som en te hanteer, kan verder geslyp word.

\section{Toepaslike perspektiewe uit die vakgebied Sosiale Intelligensie}

SI kan beskou word as 'n verdere ontwikkeling van die studie van Psigologie, maar met 'n eie inhoud en beklemtoning. In kern impliseer die vakgebied, EI, dat dit'n kennisveld is wat die kategeet nader tot selfinsig in sy eie gevoelens, motiewe en emosies kan toerus. Die vakgebied, SI, aan die ander kant, kan diensbaar wees om die kategeet tot insig in ander persone (in hierdie geval die katkisante) se emosies en sosiale situasies te bring, en om die kategeet se vaardighede om 'n bepaalde situasie te kan hanteer, te verfyn.

Die navorsing van Goleman (2006:331 e.v.; Albrecht 2005:101; Venter 2009:144-145) word nou soos volg byeengebring, ontleed en aangebied as sintese van toepaslike aspekte uit die vakgebied SI vir die kategeet as intermediêr in geloofsvorming.

Dit kan vooraf gestel word dat die navorsing van Goleman vanuit die Neurologie besliste verbande tussen ' $n$ bepaalde soort sosiale optrede en bepaalde breinfunksies lê. Afgesien van ander funksies het die brein ook die vermoë en instelling vir die sosiale verbinding en funksies van 'n mens.

\section{Toepaslike aspekte vanuit die vakgebied Sosiale Intelligensie}

As een van die belangrikste elemente van die vaardigheid van SI moet sosiale bewustheid uitgesonder word. Sosiale bewustheid omvat die vermoë om 'n ander se innerlike situasie aan te voel en sy of haar gevoelens te verstaan.

In hierdie proses van verstaan speel verskeie vaardighede 'n belangrike rol, naamlik empatie, sosiale konteks, houding, egtheid en helderheid.

Empatie hou in dat die kategeet kan aanvoel wat die katkisant voel, en as't ware in staat is om in die katkisant se skoene te gaan staan. Empatie tree veral in werking deur die kreatiewe luisteraksie as vaardigheid om te voel wat 'n ander voel deur nieverbale seine op te vang en 'n akkurate begrip vir ander se gevoelens, gedagtes en bedoeling te besit. Kortom, deur 'n gevoel van wederkerigheid te skep tussen die kategeet as kommunikeerder en die katkisant as gespreksgenoot (vgl. Goleman 2006:331 e.v.) 
Sosiale konteks is die ruimte waarin sosiale interaksie plaasvind en mense se gedrag, optrede en reaksie beïnvloed word. Gegewens vanuit die vakgebied, SI, kan in hierdie verstaan van die sosiale konteks, toerusting lewer vir die kategeet (vgl. Albrecht 2005:101).

'n Vaardigheid van die kategeet om 'n bepaalde houding ('presence') uit te straal, is noodsaaklik. Houding dui onder meer op die indruk wat iemand skep, die boodskap wat sy of haar optrede uitstraal, sy gedrag en vaardigheid, en sy gevoel van eiewaarde soos dit deur ander beleef word. Hiermee hang ook saam die doeltreffende wyse waarop die kategeet homself moet aanbied in die aksie van geloofsvorming, byvoorbeeld met die gesag waarmee die kategeet sy les aanbied (vgl. Warren 2001:144).

Met egtheid word bedoel die eerlikheid, opregtheid en integriteit waarmee die kategeet die leeraksie bemiddel in die proses van geloofsvorming. Die kategeet moet self glo wat hy of sy aan ander leer. Iemand kan nie as kategeet slaag en as gelowige druip nie, allermins in die proses van geloofsvorming.

'n Verdere moontlike bydrae wat SI as kennisveld kan lewer, is op die gebied van helder en verhelderende kommunikasie. Dit gaan hier oor die vaardigheid om duidelik te kan formuleer. Hierdie vaardigheid hang nou saam met kommunikasievermoëns om kreatief te luister, terugvoering en samevattings te bied en kernagtig en in beelde te kan kommunikeer (vgl. Venter 2009:148).

Kommunikasie en die wyse van kommunikasie kan 'n opbouende of 'n negatiewe uitwerking hê. Negatiewe kommunikasie in geloofsvorming kan neerslag vind in gevoelens en gedrag van vernedering, aggressie, frustrasie, skuld en ontoereikendheid. Opbouende kommunikasie kom na vore in gevoelens van eiewaarde, goedkeuring, bemoediging en opgewassenheid vir ' $n$ taak. Herhalende negatiewe kommunikasie met en optrede teenoor ander mense dui op 'n lae vlak van SI as vermoë en vaardigheid. Die teenoorgestelde, naamlik positiewe kommunikasie, dui op 'n hoë vlak en verfynde vermoë van SI.

Samevattend kan genoem word dat empatie, bekendheid met die sosiale konteks, die uitstraal van die regte houding in die oordra van sy boodskap, 'n gesonde gevoel van eiewaarde, egtheid en helder kommunikasie van die belangrikste fasette is wat geloofsvorming van die kant van die kategeet kan dien.

\section{Praktykteoretiese perspektiewe}

Vanuit die wisselwerking tussen die ontginde basisteoretiese en metateoretiese stof word die volgende praktykteoretiese perspektiewe nou gebied op die nadere toerusting van die kategeet in die onderrig tot geloofsvorming.

\section{Toerusting van kategete op gemeentelike vlak}

Vanuit die basisteoretiese perspektief van die kategete as gawes van die Heilige Gees tot geloofsvorming van katkisante word aan die hand gedoen dat toerusting vanuit die Bybelse gegewens wat in hierdie navorsing nader omlyn en ontgin is, in die plaaslike gemeente as toerusting vir kategete in drie Bybelstudiegeleenthede aangebied kan word. Dit kan geskied in drie periodes van een uur oor 'n hele oggend heen of in drie aandsessies. Die inhoud van hierdie sessies kan handel oor die nadere definiëring van geloof en geloofsvorming; wat die aksie van leer in 'n Bybelse sin inhou; die wyse en gesindheid waarin die kategeet in sy onderrig tot geloofsvorming optree; en die geloofsidentifikasie van katkisant met kategeet. Die wyse waarop die Bybelse perspektiewe vir elke klas in elke leeftydsfase prakties toegepas behoort te word in die klas, behoort deel te wees van die toerusting.

\section{Die toerusting van kategete in wyer verband}

Veral rondom die hantering van die toerusting van die kategeet in die wyer kerkverband, kan streekbyeenkomste gereël word en kundiges betrek word om die ontginde materiaal op metateoretiese vlak aan te bied as toerusting vir die kategeet tot geloofsvorming van katkisante. Hierin behoort aspekte soos die volgende betrek te word:

- Hoe die kategeet self tot groei in insig kom in sy of haar eie gevoelens, selfbeskouing, vermoëns en selfvertroue.

- Hoe die kategeet die vermoë verder kan ontwikkel om eie frustrasie, aggressie en ander gevoelens te kan beheer, byvoorbeeld deur swye na ' $n$ aweregse of uitdagende bewering van 'n katkisant, of om in 'n uiterste geval homof haarself uit die gesprek of situasie te onttrek.

- Die wyse waarop voortgaande insig, nie alleenlik in die kategeet nie, maar ook deur die kategeet in die katkisant se emosies en optrede kan plaasvind. Hiervoor moet die kategeet in sy ofhaar aanbieding en optrede 'n gesindheid van empatie en onderrig in vriendelikheid en in ' $n$ verhouding van ' $n$ vader met sy huisgesin toon. Hiervoor is nie alleen insig in die katkisant se persoonlikheidsamestelling nodig nie, maar ook in die breër en meer onmiddellike konteks van tyd, situasie en huislike omstandighede.

- Die wyse waarop die kategeet toegerus kan word in vaardigheid om in sy aanbieding 'n bepaalde houding ('presence') uit te straal. Dit moet vir die katkisant duidelik wees dat die kategeet self glo wat hy of sy aan die kind in geloofsvorming leer en dat die les met gesag oorgedra moet word.

- Op watter manier 'n bepaalde vaardigheid deur die kategeet aangeleer of meer afgerond kan word om in die leeraksie helder te formuleer, saam te vat, terugvoer te gee en gepaste beelde te gebruik in die aksie van geloofsvorming, en ook om gepaste vraagstelling op verskillende vlakke van kommunikasie te gebruik. Hierby is dit vir die kategeet nodig om insig te verkry in die afbrekende gevolge van negatiewe kommunikasie met die katkisant, asook van die opbouende resultate in sy positiewe kommunikasie. 


\section{Selftoerusting van die kategeet}

Die selftoerusting van die kategeet deur sy belewing van die persoonlike geloofsverhouding met God is van grondliggende belang om te onderrig tot geloofsvorming van katkisante. Die kategeet se eie gebedslewe, omgang met God deur sy Woord, bepeinsing en stilword voor God, die gepaste deel van 'n eie geloofservaring, hartseer en blydskap op 'n empatiese wyse op die regte tyd met die katkisante is alles bepalend vir die kategeet se selftoerusting.

Al hierdie aspekte bring deur die werk van die Heilige Gees verwondering by kategeet en katkisant - verwondering oor die krag en groei van geloof wat begin het by die begin - by die vorming van hierdie geloof.

\section{Erkenning}

Hierdie artikel word opgedra aan prof. Theuns F.J. Dreyer, 'n gewaardeerde kollega en geloofsgenoot oor die jare heen.

\section{Mededingende belange}

Die outeur verklaar dat hy geen finansiële of persoonlike verbintenis het met enige party wat hom nadelig kon beïnvloed in die skryf van hierdie artikel.

\section{Literatuurverwysings}

Albrecht, K., 2005, Social Intelligence: The new science of success, Wiley, New York.

Augier, M., Sharig, S.Z. \& Vendelo, M.T., 2001, 'Understanding context', Journal of Management 5(2), 125-136.

Bauer, W., 1979, A Greek-English lexicon of the New Testament and other early Christian literature, transl. W. Arndt \& F.W. Gingrich, Chicago University Press, Chicago, IL.

Bedell, J.R. \& Lennox, S.S., 1997, Handbook for communication and problem-solving skills training, Wiley, New York.

Breed, G., 1994, 'Kategese en geloofsopvoeding', ThD-proefskrif, Departement Praktiese Teologie, Potchefstroomse Universiteit vir CHO.

Breed, G. \& Venter, C.J.H., 1996, 'Sien, hoor en ken: Basisteoretiese perspektiewe op geloofsopvoeding deur die onderhouding van die Pasga: 'n Verkenning van OuTestamentiese gegewens', In die Skriflig 30(1), 57-72.

Buys, P.J., 2010, 'Vorming van ' $n$ man van God: Evaluering van internasionale debatte oor predikantsopleiding in die lig van perspektiewe uit 1 en 2 Timoteus', In die Skriflig 44(1), 47-66.

De Wet, D.C., 2003, "n Gemeenskapsgerigte model vir geloofsvorming van tieners in die verbondsgesin deur middel van simbole en rituele', PhD-proefskrif, Departement Praktiese Teologie, Universiteit van Pretoria.

Dingemans, G.D.J., 1986, In de leerschool van het geloof: Mathetiek en vakdidaktiek voor catechese en kerkelijk vormingswerk, Kok, Kampen.
Dreyer, T.F.J., 1998, 'Teologiese opleiding en spiritualiteit', Die Hervormer 19(1), 5.

Gereformeerde Kerke in Suid-Afrika, 2001, 'Heidelbergse Kategismus', in Psalmboek, pp. 33-72, N.G Kerk-Uitgewers, Wellington.

Goleman, D., 1997, Emotional intelligence, Bantam, New York.

Goleman, D., 2006, Social intelligence: The new science of human relationships, Hutchinson, London.

Groome, T.H., 1991, Sharing faith: A comprehensive approach to religious education and pastoral ministry: The way of shared praxis, Harper, San Francisco, CA.

Heidelbergse Kategismus, kyk Gereformeerde Kerke in Suid-Afrika, 2001.

Hewitt, T., 1975, The epistle to the Hebrews: An introduction and commentary, InterVarsity Press, London.

Hoffman, L., 2010, 'Kritiese elemente vir geloofsvorming in 'n kategesemodel', DThproefskrif, Departement Praktiese Teologie, Universiteit van die Vrystaat.

Joubert, P., 2009, 'Die verhouding tussen geloof as kennis en geloof as ervaring in preke van die NG Kerk', Praktiese Teologie in Suid-Afrika 24(1), 72-88.

Kruger, F.P., 2002, 'Prediking en gesindheidsverandering. 'n Prakties-teologiese studie in die lig van Hebreërs', ThD-proefskrif, Departement Praktiese Teologie, Potchefstroomse Universiteit vir $\mathrm{CHO}$.

Louw, J.P. \& Nida, E.A., 1989, Greek-English lexicon of the New Testament based on semantic domains: I, United Bible Societies, New York.

$\mathrm{Nel}, \mathrm{M} ., 2001$, Ek is die verskil: Die invloed van persoonlikheid in die prediking, CLF, Bloemfontein.

Nel, M., 2005, 'The purpose of theological training', In die Skriflig 39(3), 441-462.

Nel, M. \& Thesnaar, C., 2006, 'Theologically informed and culturally relevant youth ministry', Praktiese Teologie in Suid-Afrika 21(2), 90-112.

Rienecker, F., 1980, A linguistic key to the Greek New Testament, vol. 2, transl. \& rev. C.L. Rogers Jnr, Zondervan, Grand Rapids, MI.

Salovey, P., Mayer, J.D. \& Caruso, D., 2002, 'The positive psychology of emotional intelligence', in C.R. Snyder \& S.J. Lopez (eds.), Handbook of positive psychology, pp. 159-171, Oxford University Press, Oxford.

Schoombie, E. \& Van Zyl, E., 2011, 'Die voorkoms van depressiesimptome onder 12 en 13-jarige leerders', Tydskrif vir Geesteswetenskappe 51(1), 53-67.

Stott, J.R.W., 1997, The message of Timothy and Titus, Inter-Varsity, Leicester.

Strommen, M.P. \& Hardel, R.A., 2000, Passing on the faith: A radical new model for youth and family ministry, Saint Mary's Press, Winona, MN.

Van der Merwe, C.N., 2004, 'Kategese as middel tot heilsekerheid en heilstoe-eiening in die konteks van verbond en koninkryk', PhD-proefskrif, Departement Praktiese Teologie, Noordwes-Universiteit, Potchefstroomkampus.

Van Wyk, G. \& Venter, C.J.H., 2003, 'Die gelowige ouer as geloofsvoorbeeld, praktiesteologiese perspektiewe op toerusting', In die Skriflig 37(3), 533-544.

Venter, C.J.H., 1999, 'Die spiritualiteit van die prediker met verwysing na sy toerustingstaak', In die Skriflig 33, 187-202.

Venter, C.J.H., 2004, 'Die predikant wat houe uitdeel: Die gemeente as teiken', In die Skriflig 38(3), 429-449.

Venter, C.J.H. \& Van der Merwe, C.N., 2005, 'Die verwerkliking van die geloof in die kerklike kategese: Basisteoretiese perspektiewe', Acta Theologica 25(1), 112-132.

Venter, C.J.H., 2005, 'Aspekte van emosionele intelligensie in die lewe van die nuwe mens', In die Skriflig 39(1), 1-25.

Venter, C.J.H., 2009, 'Pastor and social intelligence', in H.J.C. Pieterse \& C.H. Thesnaar (reds.), A faithful witness, pp. 137-151, Bybelmedia, Wellington.

Vermeulen, S., 1999, EQ emotional intelligence for everyone, Zebra, Rivonia.

Warren, M., 2001, 'Catechesis and (or) religious education: Another look', in B. Roben \& M. Warren (eds.), Religious education as Practical Theology, pp. 143-145, Harper, San Francisco. 